\title{
Pertumbuhan dan Hasil Tiga Varietas Kedelai dengan Berbagai Interval Pemberian Air Irigasi di Lahan Sawah Beriklim Kering
}

\author{
Growth and Yield of three Soybean Varieties with \\ Various Irrigation Intervals at Dry Climate Rice Field
}

\author{
Nani Herawati ${ }^{1,2}$, Munif Ghulamahdi ${ }^{*}$, dan Eko Sulistyono ${ }^{3}$ \\ ${ }^{1}$ Program Studi Agronomi dan Hortikultura, Sekolah Pascasarjana, Institut Pertanian Bogor \\ ${ }^{2}$ Balai Pengkajian Teknologi Pertanian Nusa Tenggara Barat, Jl, Raya Peninjauan Nusa Tenggara Barat, Indonesia \\ ${ }^{3}$ Departemen Agronomi dan Hortikultura, Fakultas Pertanian, Institut Pertanian Bogor \\ (Bogor Agricultural University), Jl. Meranti, Kampus IPB Darmaga, Bogor 16680, Indonesia
}

Diterima 27 Desember 2016/Disetujui 4 Maret 2018

\begin{abstract}
Soybean (Glycine max L. Merrill) is an essential commodity due to its protein content and it is also as functional food which contains isoflavon as an antioxidants. Import policy is handled when there is a high demand of soybean in local market but lack of local production. This research aimed to study growth and yield of three soybean varieties with differens watering intervals in paddy field under dry climate. This research was conducted in Sesela Village, Gunung Sari Sub District, District of West Lombok, Nusa Tenggara Barat Province from July to October 2015. This research used split plot design with three replications. The main plot was irrigation intervals every (2, 9, 16, 23, 30 days) and the sub plot was soybean varieties (Anjasmoro, Burangrang, and Tanggamus). The results showed that interaction between irrigation interval and varieties influenced plant growth and yield, such as plant height, number of leaves, leaf area, 100 seeds weight and number of productive pod. Tanggamus variety has the highest number of pods of 146.33 and yield (4.2 ton hal) in paddy field.
\end{abstract}

Keywords: number of leaves, productive pod, variety, yield

\section{ABSTRAK}

Kedelai (Glycine max L. Merrill) merupakan komoditas yang cukup penting karena kaya akan kandungan protein dan merupakan pangan fungsional yang mengandung zat isoflavon sebagai antioksidan. Kebutuhan kedelai dalam negeri cukup tinggi sementara produksi dan luas panen menurun, sehingga perlu dilakukan peningkatan melalui perluasan areal tanam. Penelitian ini bertujuan untuk mendapatkan informasi pertumbuhan dan hasil tanaman tiga varietas kedelai terhadap berbagai interval pemberian air irigasi pada lahan sawah beriklim kering. Penelitian dilaksanakan di Desa Sesela, Kecamatan Gunung Sari, Kabupaten Lombok Barat, Nusa Tenggara Barat dari bulan Juli hingga Oktober 2015. Percobaan disusun menggunakan rancangan petak terpisah dengan tiga ulangan. Petak utama yang digunakan adalah interval pemberian air yang terdiri dari 5 taraf yaitu 2, 9, 16, 23, dan 30 hari sekali, sedangkan anak petak terdiri atas varietas kedelai yaitu varietas Anjasmoro, Burangrang dan Tanggamus. Hasil penelitian menunjukkan interaksi antara interval pemberian air dan varietas meningkatkan pertumbuhan yaitu tinggi tanaman, jumlah daun, luas daun, bobot 100 biji, jumlah polong produktif serta produktivitas. Varietas Tanggamus memiliki jumlah polong tertinggi sebanyak 146.33 dan produktivitas 4.2 ton ha di lahan sawah beriklim kering.

Kata kunci: jumlah daun, polong produktif, produktivitas, varietas

\section{PENDAHULUAN}

Komoditas kedelai sudah umum dimanfaatkan sebagai sumber protein dan bahan baku pembuatan tempe, tahu, kecap, serta bungkil kedelai yang digunakan sebagai pakan

\footnotetext{
* Penulis untuk korespondensi. e-mail: mghulamahdi@yahoo. com
}

ternak. Dewasa ini kedelai tidak hanya digunakan sebagai sumber protein, tetapi juga sebagai pangan fungsional yang dapat mencegah penyakit degenaratif seperti jantung koroner dan hipertensi karena mengandung zat isoflavon yang merupakan antioksidan (Balitbang Tanaman Pangan, 2008).

Tahun 2014 untuk memenuhi kebutuhan kedelai dalam negeri pemerintah telah mengimpor sebanyak 1.39 juta 
ton (BPS, 2015). Berdasarkan data BPS (2016) produksi kedelai pada tahun 2015 mencapai 963,000 ton. Konsumsi kedelai dari tahun ketahun semakin meningkat yaitu 2.35 juta ton (Atman, 2009) dan pada tahun 2018 diperkirakan akan meningkat menjadi 2.5 juta ton.

Nusa Tenggara Barat (NTB) merupakan salah satu provinsi penghasil kedelai di Indonesia dan pada tahun 2012-2013 menduduki peringkat ketiga setelah Jawa Timur dan Jawa Tengah. Karakteristik biofisik lahan dan radiasi penyinaran di NTB sesuai untuk pertumbuhan tanaman kedelai. Potensi ini memberi peluang NTB sebagai penghasil benih kedelai.

Penelitian lapangan tentang interval pemberian air untuk memenuhi kebutuhan air pada kedelai di lahan sawah beriklim kering dan untuk lahan potensial bagi pertumbuhan kedelai belum banyak dilakukan. Muhumed et al. (2014) dalam laporan penelitiannya menyebutkan dengan mengatur frekuensi pemberian air dan mengelola ketersediaan air mampu meningkatkan produktivitas kedelai. Sacita (2016) dalam penelitiannya menunjukkan bahwa varietas Argomulyo mampu beradaptasi dan lebih toleran pada musim kemarau di dalam rumah plastik dengan interval penyiraman 5 dan 10 hari sekali pada fase vegetatif dan generatif.

NTB memiliki bulan basah kurang dari 3-4 bulan dan musim kemarau berlangsung dari bulan April sampai November, berdasarkan hal tersebut daerah yang memiliki bulan basah kurang dari 3-4 bulan dan bulan kering 4-6 bulan diatas 6 bulan dimasukkan ke dalam daerah dengan tipe iklim kering (Oldeman et al., 1980). Berdasarkan hal tersebut perlu dilakukan penelitian di lapangan untuk mendapatkan pertumbuhan dan hasil biji berbagai varietas kedelai pada berbagai interval pemberian air irigasi di lahan sawah beriklim kering.

\section{BAHAN DAN METODE}

Penelitian dilaksanakan di lahan sawah beriklim kering berlokasi di Desa Sesela, Kecamatan Gunung Sari, Kabupaten Lombok Barat, Nusa Tenggara Barat pada bulan Juli hingga Oktober 2015. Penelitian menggunakan rancangan petak terpisah terdiri atas dua faktor. Faktor pertama sebagai petak utama adalah interval pemberian air (PA) yang terdiri atas beberapa taraf yaitu 2 hari sekali (A), 9 hari sekali (B), 16 hari sekali (C), 23 hari sekali (D), dan 30 hari sekali (E). Faktor kedua sebagai anak petak adalah varietas kedelai yaitu Anjasmoro, Burangrang, dan Tanggamus yang benihnya berasal dari Balitkabi sehingga terdapat 15 kombinasi perlakuan dan setiap perlakuan diulang 3 kali sehingga terdapat 45 kombinasi perlakuan. Perlakuan interval pemberian air dimulai pada 2 minggu setelah tanam. Peubah yang diamati terdiri dari komponen pertumbuhan dankomponen produksi. Datahasilpengamatan diolah dan dianalisis dengan sidik ragam taraf kesalahan 5\% apabila pengaruh perlakuan nyata maka dilanjutkan dengan uji jarak berganda duncan (Duncan multiple range test) pada taraf $\alpha 5 \%$. Pengolahan data menggunakan software SAS. Bahan tanam yang digunakan adalah pupuk Urea, SP-36, KCl, pestisida, dan insektisida kimia. Sampel tanah diambil dan dilakukan analisis di Laboratorium fisika dan kimia tanah pada Laboratorium Tanah Balai Pengkajian Teknologi Pertanian NTB dan Laboratorium Tanah IPB Bogor. Pengamatan data iklim menggunakan data logger yang dipasang pada lokasi penelitian yang diperoleh dari Laboratorium Agrometereologi dan Geofisika IPB, Bogor.

Persiapan lahan dilakukan dengan cara tanpa olah tanah (TOT), dibuat saluran irigasi dengan kedalaman $25 \mathrm{~cm}$ dan lebar $30 \mathrm{~cm}$ pada setiap petak. Petakan dibuat bedengan dengan anak petak berukuran $2 \mathrm{~m}$ x $5 \mathrm{~m}$, sehingga petak utama berukuran $2 \mathrm{~m}$ x $30 \mathrm{~m}$, jarak antar petak utama dengan petak utama yang lain $4 \mathrm{~m}$. Setiap petak utama dikelilingi saluran air yang berukuran lebar $30 \mathrm{~cm}$ dengan kedalaman $25 \mathrm{~cm}$. Pemberian air irigasi dilakukan menggunakan pompa serta air berasal dari sungai yang dihubungkan dengan pipa dan dilakukan disesuaikan dengan perlakuan yaitu interval 2, 9, 16, 23, dan 30 hari sekali.

Penanaman kedelai dilakukan dengan menggunakan jarak tanam $25 \mathrm{~cm}$ x $20 \mathrm{~cm}$, setiap lubang diberikan dua benih kedelai. Semua perlakuan diberi pupuk dasar urea $75 \mathrm{~kg} \mathrm{ha}^{-1}$, KCl $100 \mathrm{~kg} \mathrm{ha}^{-1}$, dan SP-36 $100 \mathrm{~kg} \mathrm{ha}^{-1}$ yang diberikan pada tanah dengan cara disebar. Pemberian air dilakukan dengan menghubungkan pipa saluran dari sungai ke saluran irigasi dengan pompa.

Panen dilakukan ketika semua daun sudah mulai rontok, polong berwarna kuning kecoklatan dan telah mengering. Panen untuk tanaman sampel dilakukan dengan cara mencabut tanaman dengan hati-hati. Penanganan pascapanen terdiri dari penjemuran brangkasan, pembijian, pengeringan, pembersihan dan penyimpanan. Pengubinan dilakukan dengan membuat ukuran petak pengubinan yaitu $1.5 \mathrm{~m} \mathrm{x} 4 \mathrm{~m}$.

Pengamatan meliputi umur $70 \%$ berbunga (hari), dilakukan pada saat jumlah tanaman telah berbunga $70 \%$ dari populasi tanaman. Tinggi tanaman diukur dari leher akar sampai titik ujung batang pokok tertinggi pada umur 10 minggu setelah tanam (MST), jumlah daun trifoliate pada $8 \mathrm{MST}$, luas daun pada $8 \mathrm{MST}$ (menggunakan metode gravimetri dengan mengambil seluruh sampel daun yang ada pada tanaman kemudian di gambar pada kertas gravimetri kemudian gambaran daun ditimbang). Pengamatan lain yaitu bobot 100 biji dilakukan dengan mengambil 100 biji dari 10 tanaman sampel pada saat panen, umur panen saat $70 \%$ daun telah menguning dan jumlah polong produktif saat panen.

\section{HASIL DAN PEMBAHASAN}

\section{Kondisi Umum Lahan Penelitian}

Kondisi cuaca di lokasi penelitian diperoleh dari satu set alat pengamatan cuaca meliputi alat ukur suhu udara, kelembaban udara, kecepatan angin, radiasi penyinaran, dan tekanan udara. Alat ini dilengkapi dengan data logger dan dilakukan mulai 2 MST periode Agustus hingga Oktober 2015. Hasil pengamatan di lapangan yaitu suhu ratarata $26{ }^{\circ} \mathrm{C}$, kelembaban $96 \%$, radiasi penyinaran 26.60 $\mathrm{MJ} \mathrm{m} \mathrm{m}^{-2}$, lama penyinaran rata-rata 9 jam per hari, curah hujan $0 \mathrm{~mm}$ hari, kecepatan angin 1014.772 Knot dan 
tekanan udara 1669 Kpa yang menyebabkan tekanan uap basah menjadi tinggi sehingga walaupun tidak ada hujan akan menyebabkan kelembaban menurun. Unsur cuaca di atas mendukung pertumbuhan dan perkembangan tanaman kedelai.

Iklim di wilayah inibersifat monsunal yang dipengaruhi oleh arah angin yang berasal dari Asia dan Australia. Hal ini menyebabkan walaupun terjadi kekeringan tetapi persediaan air pada sumber air di luar musim hujan masih tersedia karena dikelilingi oleh sumber air yaitu sumber air laut dan air sungai dan kelembaban cenderung tidak terlalu turun jauh. Penelitian Sacita (2016) terhadap penanaman kedelai dengan menggunakan rumah plastik dan waktu yang sama diperoleh suhu rata-rata $26^{\circ} \mathrm{C}$, intensitas radiasi perhari rata-rata 13.7 $\mathrm{MJ} \mathrm{m}^{-2}$, lama penyinaran rata-rata 7 jam per hari kelembaban udara $82 \%$, menyebabkan defisit tekanan uap tanah yang tinggi dan tekanan basah semakin tinggi. Gambaran kondisi iklim menunjukkan radiasi penyinaran yang ada di lokasi penelitian memiliki radiasi penyinaran yang jumlahnya dua kali lipat dari radiasi penyinaran yang ada di rumah plastik di wilayah Bogor (Sacita, 2016). Radiasi penyinaran didukung dengan ketersediaan air yang mencukupi akan mempengaruhi pertumbuhan dan perkembangan tanaman kedelai. Selain itu, hasil analisis tanah pada awal dan akhir penelitian menunjukkan $\mathrm{pH}$ mendekati netral sebesar 6.44 dan 6.41 dengan kondisi kesuburan yang sedang. Tanah memiliki kandungan pasir $44 \%$, debu $40 \%$, dan liat $16 \%$ bertekstur lempung. Lahan ini sesuai dengan kategori lahan untuk pertumbuhan dan perkembangan tanaman kedelai (Balitbang Tanaman Pangan, 2008).

\section{Pengaruh Interval Pemberian Air terhadap Pertumbuhan Tiga Varietas Kedelai}

Analisis sidik ragam menunjukkan bahwa terdapat pengaruh interaksi antara interval pemberian air dan varietas. Hasil uji lanjut menunjukkan bahwa tinggi tanaman pada umur 10 MST nyata dipengaruhi oleh interval pemberian air dan varietas, tanaman yang paling tinggi adalah Tanggamus dan Anjasmoro dengan interval 2 hari sekali. Akan tetapi terjadi penurunan yang nyata pada tinggi tanaman Ajasmoro jika interval pemberian air 30 hari sekali (Gambar 1). Penurunan tinggi tanaman yang lebih besar menunjukkan kedua varietas peka terhadap keterbatasan air. Pada interval pemberian air 2 dan 9 hari sekali hasil pengukuran tinggi tanaman adalah $90 \mathrm{~cm}$. Berdasarkan deskripsi varietas Tanggamus dan Anjasmoro yang dikeluarkan oleh Badan Litbang Pertanian varietas Tanggamus memiliki tinggi 67 $\mathrm{cm}$ dan varietas Anjasmoro 64-68 cm.

Ketiga varietas memiliki respon yang berbeda terhadap perbedaan interval pemberian air. Secara umum tinggi tanaman semakin rendah pada interval pemberian air yang semakin menurun, di sebabkan oleh ketersediaan air yang kurang mencukupi sehingga menyebabkan ketersediaan unsur hara dan kelarutan unsur hara dalam tanah akan berkurang. Dengan demikian transpor hara ke jaringan tanaman juga akan semakin rendah. Hal ini selaras dengan penelitian yang dilakukan oleh Nugraha et al. (2014) bahwa tanaman kedelai yang ditanam di rumah plastik dengan interval pemberian air yang dikurangi jumlahnya menyebabkan menurunnya tinggi tanaman sebesar 9.2\%. Selain itu, penelitian yang dilakukan Sharifa dan Muriefah (2015) menunjukkan pada kedelai yang diberi cekaman kekeringan dengan mengurangi intensitas pemberian air pada fase generatif juga menyebabkan berkurangnya tinggi tanaman.

Interaksi 3 varietas kedelai dengan beberapa interval pemberian air irigasi, memberikan jumlah daun tertinggi 44 helai terdapat pada perlakuan interval pemberian air 16 hari sekali pada varietas Tanggamus. Sedangkan jumlah daun terendah 16 helai terdapat pada varietas Burangrang pada interval pemberian air 30 hari sekali (Gambar 2). Tanggamus memiliki jumlah daun yang paling banyak pada setiap interval pemberian air walaupun pada kondisi pemberian air 30 hari sekali, hal ini disebabkan varietas Tanggamus lebih tahan terhadap kondisi kurang air. Burangrang memiliki jumlah daun yang paling rendah pada setiap interval pemberian air. Berdasarkan penelitian yang dilakukan Sacita

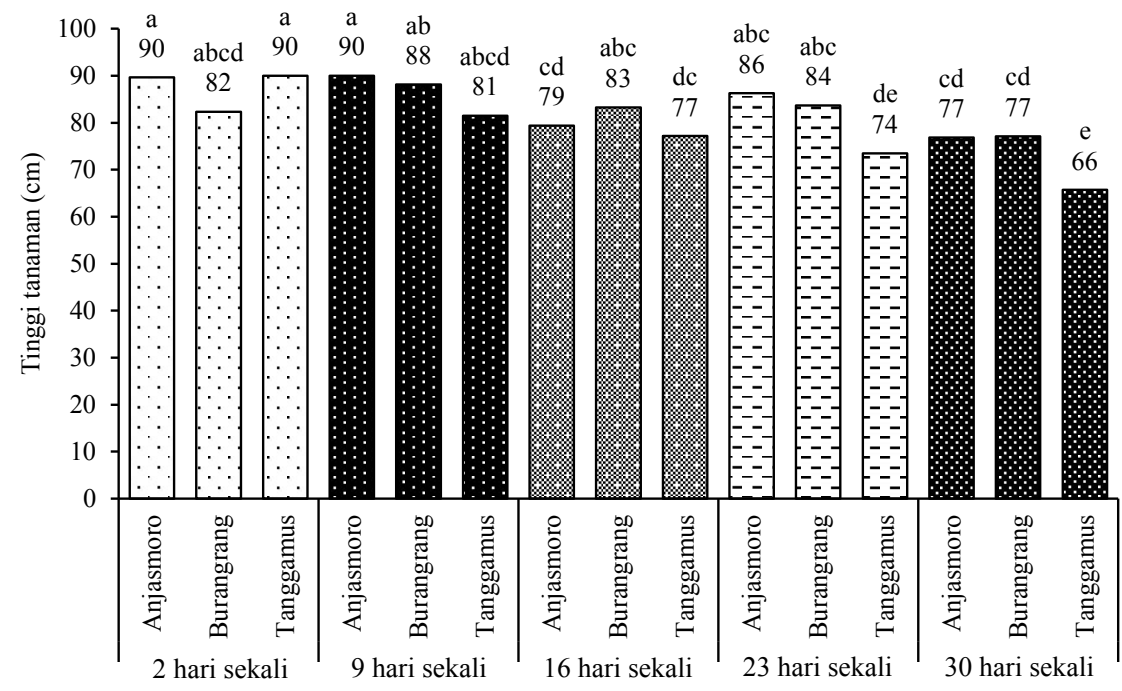

Gambar 1. Pengaruh interaksi 3 varietas kedelai dengan interval irigasi yang berbeda terhadap tinggi tanaman pada 10 MST 


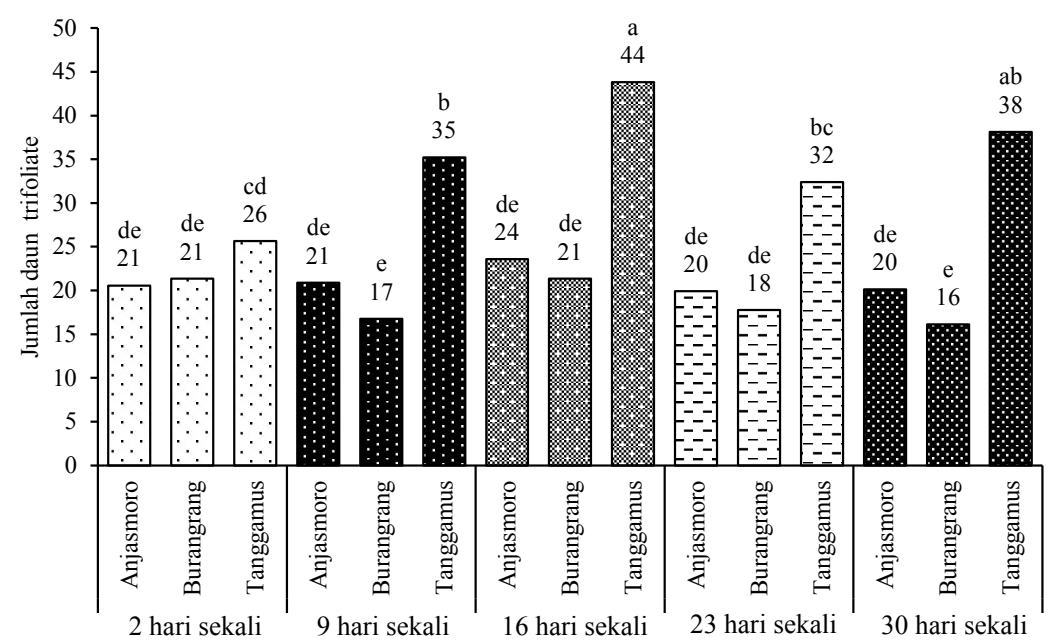

Gambar 2. Pengaruh interaksi 3 varietas kedelai dengan interval irigasi yang berbeda terhadap jumlah daun pada 8 MST

(2016) jumlah daun yang sedikit disebabkan oleh adanya gangguan pertumbuhan serta beberapa upaya adaptasi yang dilakukan oleh tanaman terhadap berkurangnya air yang ada pada jaringan untuk menghadapi kehilangan air yang lebih besar lagi.

Perlakuan interval pemberian air dan varietas nyata meningkatkan luas daun kedelai. Kombinasi perlakuan interval pemberian air 2 dan 9 hari sekali pada Anjasmoro menghasilkan luas daun tertinggi yaitu $244 \mathrm{~cm}^{2}$ dan $271 \mathrm{~cm}^{2}$, dan berbeda nyata dengan perlakuan interval pemberian air 30 hari sekali pada Burangrang $\left(36 \mathrm{~cm}^{2}\right)$ (Gambar 3). Hal ini sejalan dengan penelitian yang dilakukan oleh Sarawa et al. (2014) dimana interval penyiraman air 2 hari sekali memberi respon luas daun tertinggi pada pertanaman kedelai. Menurut Sulistyono et al. (2012) respon fisiologi pertama yang dialami tanaman ketika tanaman mengalami kekurangan air atau tercekam kekeringan adalah penurunan ukuran daun. Hal ini akan menyebabkan penurunan jumlah stomata yang akan mempengaruhi proses fotosisintesis. Perubahan ukuran daun merupakan mekanisme adaptasi tanaman terhadap kekurangan air walaupun ukuran daun semakin mengecil akan tetapi proses fotosintesis akan tetap berlangsung.

Perlakuan interval pemberian air memberikan respon yang berbeda nyata terhadap umur berbunga. Interval pemberian air 2 dan 9 hari sekali pada ketiga varietas memiliki umur berbunga yang lebih lama yaitu 37 hari dan berbeda nyata dengan interval pemberian air 30 hari sekali pada ketiga varietas memberikan respon umur berbunga paling cepat yaitu 30 hari. Berdasarkan deskripsi varietas umur berbunga varietas Anjasmoro 35.7, varietas Burangrang 35 hari dan varietas Tanggamus 35 hari (Balitbang, 2008) (Gambar 4). Dapat dilihat bahwa respon ketiga varietas terhadap pemberian air yang semakin menurun menunjukkan umur berbunga yang semakin cepat. Munawaroh et al. (2016) dalam penelitian tanaman padi menyampaikan bahwa umur berbunga berkorelasi nyata terhadap efesiensi pemakaian air yang menyangkut tingkat ketersedian air pada padi, pemberian air yang menurun menyebabkan umur berbunga tanaman padi semakin cepat. Sabaruddin et al. (2011) dalam penelitiannya menunjukkan pada tanaman kacang hijau pemberian air irigasi yang teratur akan memperpanjang masa pembungaan. Menurut Lin et al. (2007) umur berbunga yang cepat disebabkan oleh adanya cekaman kekeringan.

\section{Pengaruh Interval Pemberian Air terhadap Produksi Tiga Varietas Kedelai}

Kombinasi perlakuan antara interval pemberian air dan varietas berpengaruh sangat nyata terhadap umur panen. Pada interval pemberian air 2, 9, 16, 23, dan 30

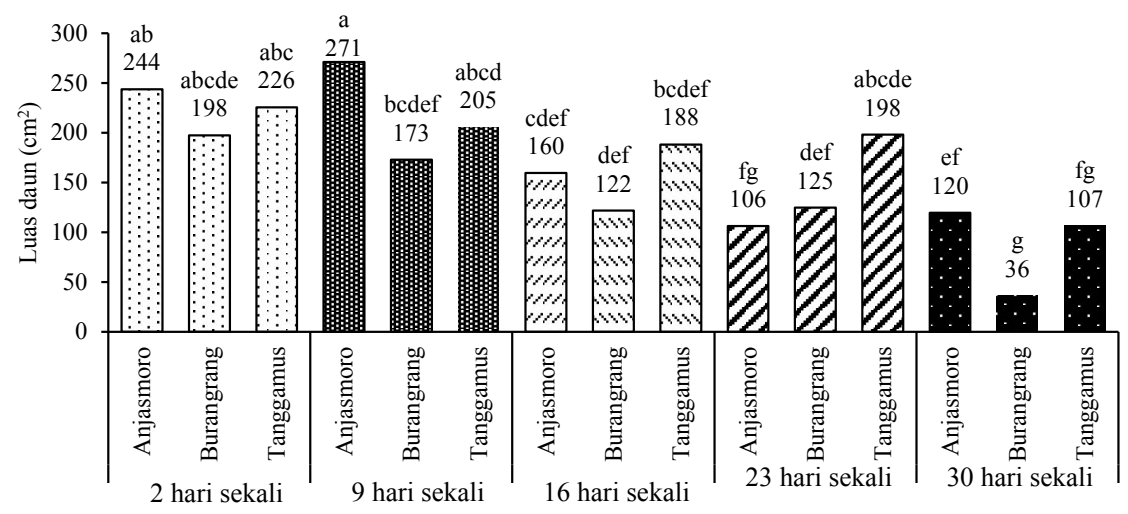

Gambar 3. Pengaruhinteraksi 3 varietas kedelai dengan interval irigasi yang berbeda terhadap luas daun pada 8 MST 


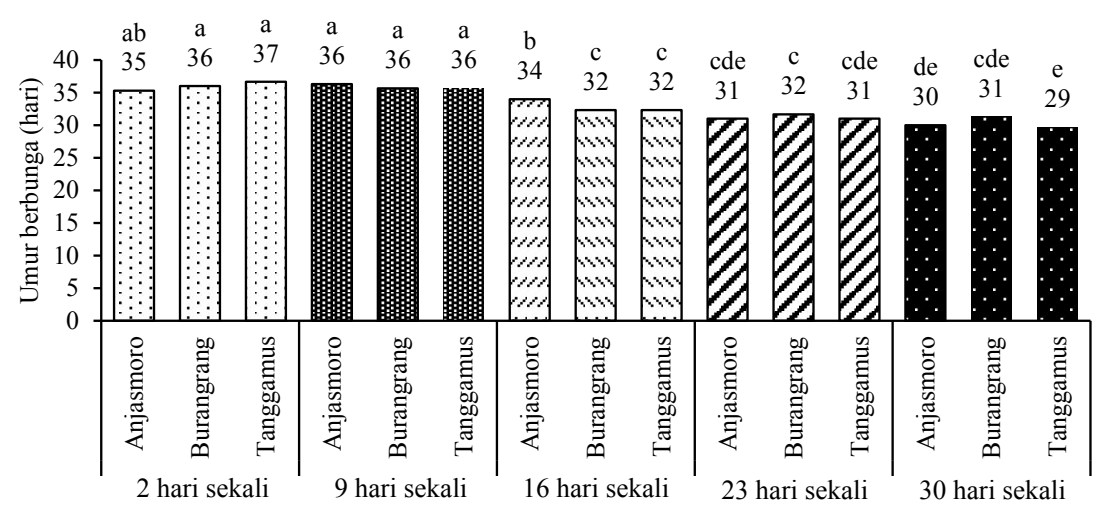

Gambar 4. Pengaruh interaksi 3 varietas kedelai kombinasi perlakuan interval pemberian air terhadap umur berbunga

hari sekali pada varietas Tanggamus menunjukkan umur panen lebih lama (100 hari) setelah tanam dibandingkan dengan Burangrang (89 hari) dan Anjasmoro (92 hari); berdasarkan deskripsi varietas, Tanggamus dan Anjasmoro memiliki umur panen yang lebih lama berkisar 82.5- 92.5 hari sementara Burangrang memiliki umur panen 80 hari (Tabel 1). Tanaman akan berusaha mempercepat siklus hidupnya untuk menghindari cekaman kekeringan. Varietas Tanggamus lebih tahan terhadap cekaman kekeringan sehingga mampu bertahan terhadap kondisi keterbatasan air pada tanaman.

Pengaruh interaksi interval pemberian air dan varietas kedelai nyata pada bobot 100 biji. Varietas Burangrang menunjukkan nilai pengamatan bobot 100 biji tertinggi pada semua interval pemberian air, sedangkan varietas Tanggamus menunjukkan nilai pengamatan bobot 100 biji paling rendah pada semua interval pemberian air dengan nilai terendah $10.39 \mathrm{~g}$ pada perlakuan pemberian air 30 hari sekali (Tabel 1). Berdasarkan deskripsi varietas, Tanggamus memiliki bobot 100 biji sebesar 11g, sementara Burangrang memiliki bobot 100 biji $17 \mathrm{~g}$ dan Anjasmoro $15.3 \mathrm{~g}$. Interval pemberian air yang semakin berkurang mengakibatkan tanaman mengalami kekeringan hal ini memberikan dampak terhadap menurunnya produksi hasil biji-bijian (Olievera et al., 2013). Pemberian air yang semakin jarang dilakukan menyebabkan tanaman kekurangan air sehingga proses generatif pada stadia kematangan terganggu (Anjum et al. 2013). Kondisi air yang mencukupi pada stadia kematangan akan membantu proses metabolisme pada tanaman yang kemudian mendukung fotosintat yang diakumulasikan pada biji. Hal ini selaras dengan penelitian yang dilakukan oleh Chafi dan Gohari (2013) pada tanaman kedelai yang ditanam di Iran bahwa pemberian air irigasi dapat meningkatkan bobot 100 biji tanaman kedelai. Amiri dan Shahram (2014) juga melaporkan hasil penelitiannya bahwa pemberian air irigasi dapat mempengaruhi bobot 100 biji pada tanaman kedelai.

Interaksi interval pemberian air dan varietas memberikan pengaruh yang nyata terhadap jumlah polong produktif. Perlakuan terbaik terhadap jumlah polong adalah pemberian interval irigasi 2 dan 16 hari sekali pada varietas Tanggamus, di mana menghasilkan jumlah polong tertinggi 145.60 dan 146.33 polong. Hasil tersebut berbeda nyata dengan varietas Burangrang (55.1 polong) dan Anjasmoro (65.47 polong) pada interval pemberian air 30 hari sekali (Tabel 1). Interval pemberian air yang semakin jarang mengakibatkan tanaman tidak mendapatkan air pada saat dibutuhkan; pada pemberian air 2 dan 16 hari sekali tanaman mendapatkan air saat fase tanaman membutuhkan air yaitu fase berbunga dan pengisian polong, sementara pemberian air 30 hari sekali dilakukan saat tanaman tidak membutuhkan air sehingga akan menghambat proses

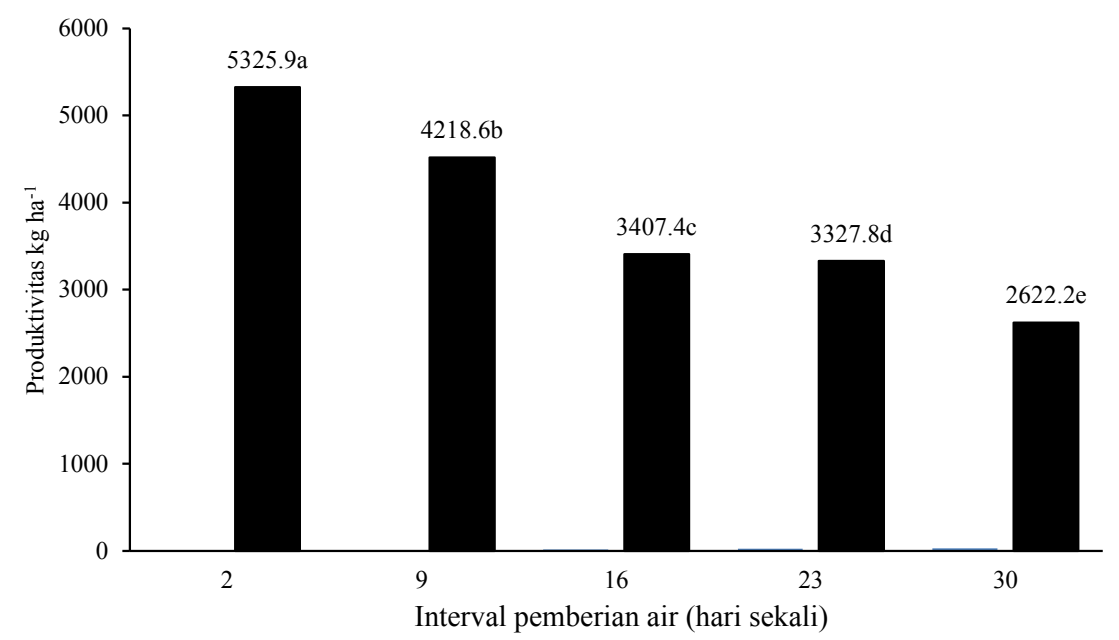

Gambar 5. Pengaruh faktor tunggal interval pemberian air terhadap produktivitas kedelai 
pembungaan dan hal ini akan berdampak pula pada pengisian polong. Hal yang sama terjadi pada penelitian yang dilakukan oleh Comlekcioglu dan Simsek (2011) pada tanaman kedelai di wilayah Turki yang dilaporkan bahwa interval irigasi yang menurun menyebabkan produksi polong menurun. Tersedianya air pada saat tanaman membutuhkan air menyebabkan daun hijau lebih lama dan aktivitas fotosintesis akan meningkat sehingga fotosintat yang akan dihasilkan cukup untuk memenuhi kebutuhan tanaman pada fase vegetatif, pembentukan, dan pengisian polong. Pengaruh interval irigasi tiga varietas kedelai nyata berpengaruh terhadap produksi biji kedelai. Pengaruh faktor tunggal air, pemberian air 2 hari sekali menghasilkan total produksi biji tertinggi sebesar 5.32 ton ha $^{-1}$ dan hasil nyata terendah dengan pemberian air 30 hari sekali sebesar 2.62 ton $\mathrm{ha}^{-1}$. Candogan et al. (2013) menyatakan bahwa produksi biji kedelai menurun seiring dengan meningkatnya cekaman kekeringan pada pertanaman kedelai. Interaksi antar varietas dan tingkat pengurangan pemberian air akan mempengaruhi pertumbuhan dan hasil tanaman kedelai (Mapegau, 2006).

Varietas yang paling sesuai digunakan untuk kondisi kekurangan air adalah varietas Tanggamus karena pada semua nilai pengamatan terhadap komponen produksi dengan interval pemberian air 23 hari sekali dan 30 hari sekali varietas ini mampu tumbuh dengan baik dan memiliki tingkat kehijauan daun yang lebih lama. Meskipun demikian, umur panen pada varietas ini lebih panjang. Varietas Tanggamus juga memiliki jumlah polong yang lebih tinggi dibandingkan dengan varietas Burangrang dan Anjasmoro. Hal ini juga selaras dengan penelitian yang dilakukan oleh Bachtiar et al. (2015) bahwa varietas Tanggamus adalah varietas yang cukup adaptif dan toleran pada budidaya di lahan kering.

Biaya membayar tenaga yang dibutuhkan satu kali dalam memasukkan air menggunakan pompa yaitu Rp 25,000.00 dengan kondisi lahan yang sumber airnya berada dan berasal dari sungai.

Tabel 1. Umur panen, bobot 100 biji dan jumlah polong produktif 3 varietas kedelai dengan interval pemberian air yang berbeda

\begin{tabular}{|c|c|c|c|c|}
\hline \multicolumn{2}{|c|}{ Perlakuan } & \multirow{2}{*}{$\begin{array}{l}\text { Umur panen } \\
\text { (HST) }\end{array}$} & \multirow{2}{*}{$\begin{array}{l}\text { Bobot } 100 \text { biji } \\
(\mathrm{g})\end{array}$} & \multirow{2}{*}{$\begin{array}{l}\text { Jumlah polong produktif } \\
\text { (buah) }\end{array}$} \\
\hline Interval (hari) & Varietas & & & \\
\hline \multirow[t]{3}{*}{2} & Anjasmoro & $91.67 b$ & $20.07 b c$ & $113.10 \mathrm{bc}$ \\
\hline & Burangrang & $89.00 \mathrm{c}$ & $22.13 \mathrm{a}$ & $117.93 b$ \\
\hline & Tanggamus & $100.00 \mathrm{a}$ & $12.33 \mathrm{~g}$ & $145.60 \mathrm{a}$ \\
\hline \multirow[t]{3}{*}{9} & Anjasmoro & $89.00 \mathrm{c}$ & $18.63 \mathrm{~cd}$ & $90.30 \mathrm{~cd}$ \\
\hline & Burangrang & $86.66 \mathrm{~d}$ & $20.69 b$ & 73.03de \\
\hline & Tanggamus & $100.00 \mathrm{a}$ & $12.57 \mathrm{fg}$ & $134.50 \mathrm{ab}$ \\
\hline \multirow[t]{3}{*}{16} & Anjasmoro & $85.33 \mathrm{de}$ & $17.97 \mathrm{~d}$ & 77.90de \\
\hline & Burangrang & $85.33 \mathrm{de}$ & $18.88 \mathrm{~cd}$ & $66.63 \mathrm{de}$ \\
\hline & Tanggamus & $100.00 \mathrm{a}$ & $12.19 \mathrm{~g}$ & $146.33 a$ \\
\hline \multirow[t]{3}{*}{23} & Anjasmoro & $84.00 \mathrm{ef}$ & $18.50 \mathrm{~d}$ & 70.50de \\
\hline & Burangrang & $82.67 f$ & $18.73 \mathrm{~cd}$ & $57.13 \mathrm{e}$ \\
\hline & Tanggamus & $100.00 \mathrm{a}$ & $11.22 \mathrm{~g}$ & $130.37 \mathrm{ab}$ \\
\hline \multirow[t]{3}{*}{30} & Anjasmoro & $79.00 \mathrm{~g}$ & $13.83 \mathrm{ef}$ & $65.47 \mathrm{de}$ \\
\hline & Burangrang & $79.00 \mathrm{~g}$ & $14.42 \mathrm{e}$ & $55.10 \mathrm{e}$ \\
\hline & Tanggamus & $100.00 \mathrm{a}$ & $10.39 \mathrm{~h}$ & $109.67 \mathrm{bc}$ \\
\hline
\end{tabular}

Keterangan: Angka-angka yang diikuti oleh huruf yang sama pada masing-masing peubah menunjukkan tidak berbeda nyata berdasarkan uji DMRT pada taraf $\alpha=5 \%$

\section{KESIMPULAN}

Interval pemberian air dan varietas nyata berpengaruh terhadap pertumbuhan dan produktivitas kedelai dilahan sawah beriklim kering. Interaksi kombinasi perlakuan pemberian air dan varietas juga meningkatkan tinggi tanaman, jumlah daun, luas daun, jumlah polong tanaman, serta bobot 100 biji per tanaman. Pada ketersediaan air rendah, varietas Tanggamus dapat menjadi pilihan untuk dikembangkan. Berdasarkan hasil penelitian, varietas
Tanggamus memiliki jumlah polong tertinggi 146.33 serta pemberian air 2 hari sekali nyata meningkatkan produksi hasil biji sebesar 5.32 ton ha $^{-1}$ pada lahan sawah beriklim kering.

\section{UCAPAN TERIMAKASIH}

Terimakasih disampaikan kepada Badan Penelitian dan Pengembangan Pertanian atas bantuan biaya penelitian sesuai dengan SK Nomor: 146/Kpts/KU.010/I.1/08/2015 tanggal 11 Agustus 2015. 


\section{DAFTAR PUSTAKA}

Amiri, I., Sahram, R. 2013. Effect of irrigation and methanol on yield and yield components in soybean (Glycine $\max ($ L.) Murr.). Indian J. Fundamental Appl. Life Sci. 4:387-395.

Anjum, A.S., Ehsannullah, X. Lania,W. Longchang, S.M. Farrukh. 2013. Exogeneous benzoic acid (BZA) treatment can induce drought tolerance in soybeans plants by improving gas exchange and chlorophyl contents. Aus. J. Crop. Sci. 7:555-560.

Atman, 2009. Strategi peningkatan produksi kedelai di Indonesia. J. Ilmiah Tumbuhan 8:39-45.

Bachtiar, M. Ghulamahdi, M. Melati, D. Guntoro, A. Sutandi. 2015. Nitrogenase activity and plant physiological process of soybean under saturated soil culture on mineral and peaty mineral soil. IJSBAR. 24:332-347.

Badan Penelitian dan Pengembangan Pertanian. 2008. Petunjuk Teknis Budidaya Kedelai. Kementerian Pertanian.

[BPS] Badan Pusat Statistik. 2015. Statistik Pertanian Indonesia. Badan Pusat Statistik dan Direktorat Jendral Tanaman Pangan. Jakarta. http://www. bps.go.id [20 Agustus 2016].

[BPS] Badan Pusat Statistik. 2016. Statistik Pertanian Indonesia. Badan Pusat Statistik dan Direktorat Jenderal Tanaman Pangan. Jakarta. http://www. bps.go.id [20 Agustus 2016].

Candogan, B.N., M.Sincik, H. Buyukcangaz, C. Demirtas, A.T. Goksoy, S.Yazgan 2013. Yield quality and crop water stress index relationships for deficit irrigated soybean (Glycine max L. Merril ) in sub - humid climatic conditions J. Agric. Water Manag. 113-121.

Chafi, A.A., A.A. Gohari. 2013. The effect of various irrigation regimes and moisture variations and water infiltration in soil on yield and water use efficiency in soybean (Glycine max). Int. J. Farming Appl. Sci. 2:27-31.

Comlekcioglu, N., M. Simsek. 2011. Effects of deficit irrigation on yield and yield components of vegetable soybean (Glycine $\max (\mathrm{L})$. Murr). In semi-arid conditions. African J. Biotechnol. 10:6227-6234.

Oldeman, L.R., I. Las, Muladi. 1980. The agroclimatic maps of Kalimantan, Maluku, Irian Jaya and Bali, West and East Nusa Tenggara. Central Research Institute for Agriculture. Bogor.
Oliveira, D.E., H. Bramley, K.H.M. Siddique, S. Henty, J. Berger, J.A. Palta. 2013. Can elevated $\mathrm{CO}_{2}$ combined with high temperature ameliorate the effect of terminal drought in wheat?. Func. Plant Biol. 40:160-171.

Lin, M.K.H.B., H.Y. Lee, G.E. Varkonyi, K.I. Taoka, E. Miura, C.B. Xocostle, K. Gendler, R.A. Jorgensen, B. Phinney, T.J. Lough, W.J. Lucas. 2007. Flowering locus protein may act as the long distance florigenic signal in the cucurbits. J. Plant Physiol. 132:186195.

Mapegau. 2006. Pengaruh cekaman air terhadap pertumbuhan dan hasil kedelai (Glycine $\max$ L. Merril). J. Ilmiah Pertanian 41:43-51.

Muhumed, M.A., S. Jusop, C.T.B. P.E.M. Wahab, Q.A. Panhwar. 2014. Effects of drip irrigation frequency, fertilizer sources and their interaction on the dry matter and yield components of sweet corn. J. Crop. Sci. 8:223-231.

Munawaroh, L., E. Sulistyono, I. Lubis, 2016. Karakter morfologi dan fisiologi yang berkaitan dengan efisiensi pemakaian air pada beberapa varietas padi gogo J. Agron. Indonesia 44:1-7.

Nugraha, S.Y., T. Sumarni, E. Sulistyono. 2014. Pengaruh interval waktu dan tingkat pemberian air terhadap pertumbuhan dan hasil kedelai (Glycine $\max$ (L.) Merril). J. Produksi Tanaman 2:552-559.

Sabaruddin, L., R. Hasid, Muhidin, A.A. Anas. 2011. Pertumbuhan, produksi dan efisiensi lahan dan sistem tumpang sari jagung dan kacang hijau dengan interval penyiraman yang berbeda. J. Agron. Indonesia 39:153-159.

Sacita, A.S. 2016. Respon tanaman kedelai (Glycine max L.) terhadap cekaman kekeringan pada fase vegetatif dan generatif. Tesis. Sekolah Pascasarjana. Institut Pertanian Bogor. Bogor.

Sarawa, J.A. Makmur, M. Maski. 2014. Pertumbuhan tanaman kedelai pada berbagai interval penyiraman dan takaran pupuk kandang. J. Agroteknos. 4:78-86.

Sharifa, A. Muriefah. 2015. Effect of paclobutrazol on growth an physiological attributes of soybean (Glycine max) plants grown under water stress conditions. Int. J. Adv. Res. Biol. Sci. 2:81-93.

Sulistyono, E., Suwarno, I. Lubis, Deni. 2012. Pengaruh frekuensi irigasi terhadap pertumbuhan dan produksi lima galur padi sawah. Agrovigor 1:1-7. 